\title{
Building a long-time series for weather and extreme weather in the Straits Settlements: a multi-disciplinary approach to the archives of societies
}

\author{
Fiona Williamson \\ School of Social Sciences, Level 4, Singapore Management University, 90 Stamford Road, 178903, Singapore \\ Correspondence: Fiona Williamson (fwilliamson@smu.edu.sg)
}

Received: 29 October 2020 - Discussion started: 12 November 2020

Revised: 23 February 2021 - Accepted: 3 March 2021 - Published: 7 April 2021

\begin{abstract}
In comparison to the Northern Hemisphere, especially Europe and North America, there is a scarcity of information regarding the historic weather and climate of Southeast Asia and the Southern Hemisphere in general. The reasons for this are both historic and political, yet that does not mean that such data do not exist. Much of the early instrumental weather records for Southeast Asia stem from the colonial period and, with some countries and regions changing hands between the European powers, surviving information tends to be scattered across the globe making its recovery a long and often arduous task. This paper focuses on data recovery for two countries that were once joined under British governance: Singapore and Malaysia. It will explore the early stage of a project that aims to recover surviving instrumental weather records for both countries from the late 1780 s to the 1950 s, with early research completed for the Straits Settlements (Singapore, Penang and Malacca) between 1786 and 1917. Taking a historical approach, the main focus here is to explore the types of records available and the circumstances of their production. In so doing, it will consider the potential for inaccuracy, highlight gaps in the record and use historical context to explain how and why these problems and omissions may have occurred. It will also explore the availability of narrative and data evidence to pinpoint extreme periods of weather such as drought or flood and consider the usefulness of historical narrative in identifying and analysing extreme events.
\end{abstract}

\section{Introduction}

There is now extensive and convincing literature citing the value of extended instrumental observational datasets of past weather conditions for studying climatic trends and variability and for identifying potential anthropogenic climatic changes (Ashcroft et al., 2014; Brázdil et al., 2010; Brönnimann et al., 2018b, 2019). In particular, instrumental observations, usually covering a period of 200 years or more, are considered vital for calibrating the differences between natural proxy reconstructions and model simulations (Brohan et al., 2012; Brönnimann et al., 2018b, 2019). The instrumental record for Southeast Asia however is very patchy, leading to less accurate climate reconstructions and even grey areas (Brönnimann et al., 2019).

The effectiveness of, for example, the Twentieth Century Reanalysis (20CR), which relies on data assimilation from surface observations of synoptic pressure to generate a fourdimensional global atmospheric dataset, improves with improved data quality and quantity across longer time periods (Compo et al., 2011; Brönnimann et al., 2018a). Relatedly, while there is a small amount of literature on extreme events - such as flood and droughts - that have impacted on this region, there is very little for the Malay Archipelago specifically. While there is potential here for improving the long record of climate-induced disasters (Brázdil, 2018), from a historical climatology perspective there is also great potential for studies that investigate environmental and climatic catalysts for socio-cultural and political change (Lee et al., 2017; Hsiang and Burke, 2014) or exploring long-term patterns of human-environment interaction (Brook, 2010; Bankoff, 2003). 


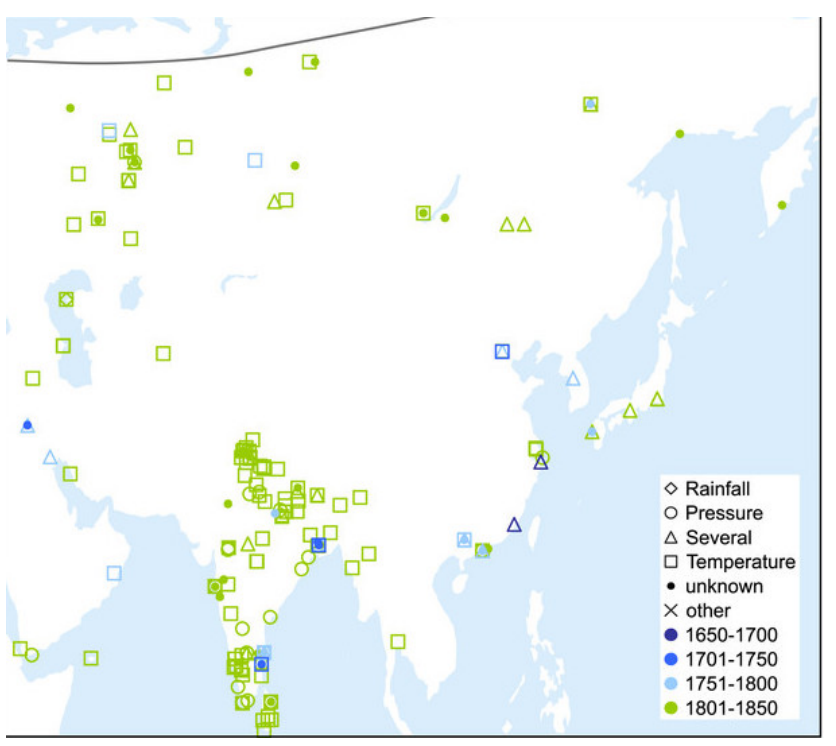

Figure 1. Series inventoried for Asia pre-1850 (Fig. 5 from Brönnimann et al., 2019).

This article focuses on surviving, known records for the Straits Settlements, now part of modern Singapore and Malaysia. The Straits Settlements were a collection of British colonies established as one administrative unit under the English East India Company from 1826 to 1867 and thereafter under the British Colonial Office until 1946, though British settlements had existed on the peninsula since 1786. The chief areas under this arrangement comprised Penang Island, Singapore, Malacca and later Christmas Island, along with other sub-regions including Province Wellesley (now mainland Penang), the Dindings (now Manjung, southwest Perak) and Labuan (Sabah, East Malaysia). The bulk of the instrumental records for the 19th century are centred on urban or peri-urban areas, due to the fact that British influence was less widespread in the rural areas and interior at this time. With the exception of a few isolated observations made on plantations or during unusual or extreme weather events, rural recording only really began in earnest during the 20th century. It could be argued that meteorological recording moved through several distinct phases, with a military and medical drive across the first phase, roughly 1800-1845, an interim period of fairly loose private enterprise across the $1850 \mathrm{~s}$ and early 1860 s, followed by a push to integrate weather more firmly into administrative practices. Then, from 1869 , weather watching was introduced formally as part of the medical department's services until the early 20th century. Thereafter the challenges of the newly created aviation industry, especially acute during the First World War, placed increasing pressure on the government to create a centralised and dedicated meteorological department, which began operations in 1929.

\section{Methods}

This dataset is based on instrumental observations for the Straits Settlements ca. 1786 to 1917. It is intended to - eventually - form the core of a larger body of data that span the whole of British Malaya, covering areas known as the Federated Malay States, including Selangor, Perak, Negri Sembilan and Pahang, for which data were increasingly collected under direction of the British colonial authorities after the 1880s. Instrumental observations for this area are largely to be found in historic archives and libraries covering the period of British colonial rule. Thus, holdings are located in the national archives of both Singapore and Malaysia, the National Library Board of Singapore (both in-house and online repositories), especially in documents such as government gazettes and newspapers. However, observations have also been identified in contemporary scientific, horticultural and agricultural journals as well as in overseas archives and libraries, especially The National Archives (UK), the UK Meteorological Office Library and Archive, the British Library, and the Cambridge Library and Archives (UK).

The dataset covered in this article represents several years' worth of research under the auspices of the international Atmospheric Circulation Reconstructions over the Earth (ACRE) initiative for Southeast Asia, a project designed to facilitate the recovery of instrumental terrestrial and marine observations from historical documents, with the ultimate aim of digitising them in electronic formats to share publicly with research communities across the world. This project also has close links to the UK Newton Fund's Climate Science to Service Partnership for China (ACRE China under CSSP China) (Scaife et al., 2020). Data found are catalogued, imaged when not already in digital format, and digitised. Ultimately, ACRE-facilitated data are deposited in global weather data repositories such as the International Surface Pressure Databank (ISPD) and the new Copernicus C3S Data Rescue Service. Here, it can be used for climate reanalysis tools and platforms, including the NOAA-CIRES-DOE Twentieth Century Reanalysis (20CR). The dataset presented here in this paper represents only those data which have been through all stages of recovery from archival original form to fully digitised and usable sources. Much more has been uncovered and is yet to be digitised, especially for the post- 1917 period and for the more rural states of Malaysia. Completed datasets are available on request to ACRE.

While the predominant focus of the ACRE project has been instrumental data, the project has also unearthed vast quantities of narrative accounts of weather, especially extreme weather, during the course of research. While this is not currently in any comprehensive publicly available form, it is being used to provide context to instrumental data across a number of funded historical projects with other organisations (see Allan et al., 2016). 


\section{Results}

Table 1 highlights data that have been recovered and the current status.

\section{Discussion}

\subsection{Historical sources: $1786-1845$}

The first weather observations to be made in the Straits Settlements were by military officers engaged in explorative studies of the regional climate for strategic and economic purposes and by doctors whose concern was to establish the "healthiness" of the region for European colonisation (Ward, 1830). The first known such records were made within a few months of the English East India Company (EEIC) taking possession of Penang (then Prince of Wales Island) in August 1786 (Bonney, 1965). Francis Light, the man then in charge of this strategic venture, recorded observations of wind and weather from Fort William, the EEIC's newly established military base across the October of that year. While only a short account, these data remain the first continuous terrestrial observations made by the British in what would within a few decades become the Straits Settlements. The next weather records were made under British Resident at Malacca, William Farquhar in 1809; in Singapore during 1815-1816; and in Penang also in 1815-1816. There is some confusion over the originator of these records. Farquhar was British resident at Malacca from 1802 and of the newly founded Singapore from 1819 until 1823 and is often credited with making the observations. However, although the readings made in Malacca during 1809 connect with his time in residence, the Singapore and Penang sets offer complications. The timeframe for the Penang observations overlaps with those for Singapore, which were more likely made under Lieutenant Colonel Monckton Coombes, an officer of the Madras Native Infantry under the English East India Company and appointed town mayor of Penang until 1825 (Bastin, 2014). For Singapore, with observations continuing until the end of 1824, it is unlikely that Farquhar made these himself. He had been dismissed from his post in late 1822 by Stamford Raffles and, although he had continued living in Singapore, he was stabbed in March 1823 by a local merchant with a personal grudge. Both circumstances - along with his important role as resident - suggest that, although he may have signed off on the observations personally, he was likely delegating the physical task of daily recording to a subordinate. Indeed, in some accounts, the EEIC Bengal Native Infantry officer Charles Edward Davies is credited with making the Singapore readings. It would not be too far a stretch of the imagination to consider Davies the originator. The measurements themselves were made using EEIC ship instruments, these being the only ones available in Singapore at that time, a fact that also explains the ab- sence of rain gauge data - an instrument normally reserved for terrestrial, not marine, use.

Thereafter, a few years of observations for Singapore alone were printed in the local press across the late 1830s, but their originator is currently unknown. A clue from the same newspaper in 1840 (The Singapore Free Press and Mercantile Advertiser, 5 March 1840, p. 3) suggests that these may have been made by a private individual, rather than as part of a military or formal endeavour as the earlier ones had been, and their lack of mention in any scientific journal of the period perhaps supports this theory. Another dataset was produced by the American missionary Joseph S. Travelli for 2 years from 1839, but the next major, comprehensive dataset to have been produced was that made during the magnetic research of EEIC Lieutenant Charles Elliot.

Unlike the earlier observations, for which little survives bar the abstracts, Elliot's dataset is both detailed and complete. Elliot was stationed in Singapore to establish and run a magnetic observatory between 1841-1845. It was part of a global experiment, sponsored by the British Royal Society and the British Association for the Advancement of Science (BAAS), to create a linked system of observatories and weather stations to investigate magnetism, astronomy and weather, more commonly known as the "Magnetic Crusade" (Cawood, 1979). Elliot's observatory was described as small but well designed. Air flow was maximised by the placement of open windows, and direct sunlight was prevented from reaching the meteorological instruments. The walls were $45.7 \mathrm{~cm}$ thick and painted white in order to reflect rather than retain heat (Elliot, 1849). For 4 years, Elliot and his small team - comprised of locally hired assistants and observers - worked on a shoe-string budget making hourly magnetic, temperature and pressure observations from this building. Elliot himself lived on site, and it was largely down to his tireless efforts to record and publish the observations that we still have access to this incredible resource today, now digitised. He also made 2 months of readings while on a trip to Borneo in 1842. Sadly, the observatory was closed in 1845 , due to the withdrawal of finances for this aspect of the magnetic project in Singapore, the instruments sent to India for re-use at Bombay (now Mumbai), and the building was left empty for several years.

Several early-19th century studies were conducted using these early datasets, especially by colonial officers and scholars interested in monitoring long-term changes in rainfall. James Richardson Logan, for example, founder of the Journal of the Indian Archipelago and Eastern Asia, published an article on the climate of Penang Island in 1848 (Logan, 1848), as too did Lieutenant Colonel James Low (Low, 1836), coroner Dr Robert Little (Little, 1848), and apothecary and medical assistant J. J. L. Wheatley (Wheatley, 1881). All attributed changes in rainfall to the rampant deforestation that had been taking place over the first years of British settlement, virgin jungle making way for plantation, urbanisation and infrastructure (Ward, 1830). 


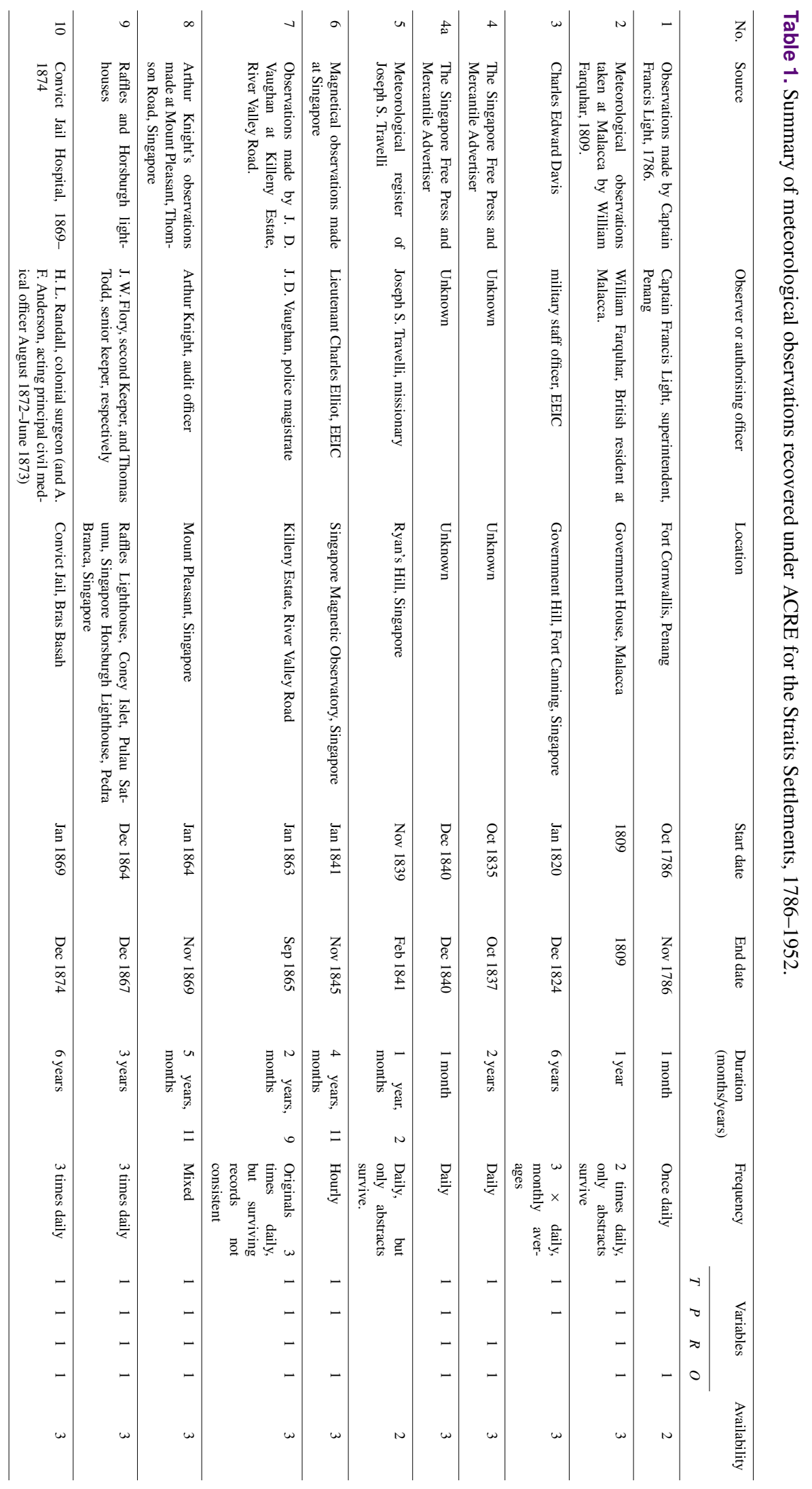




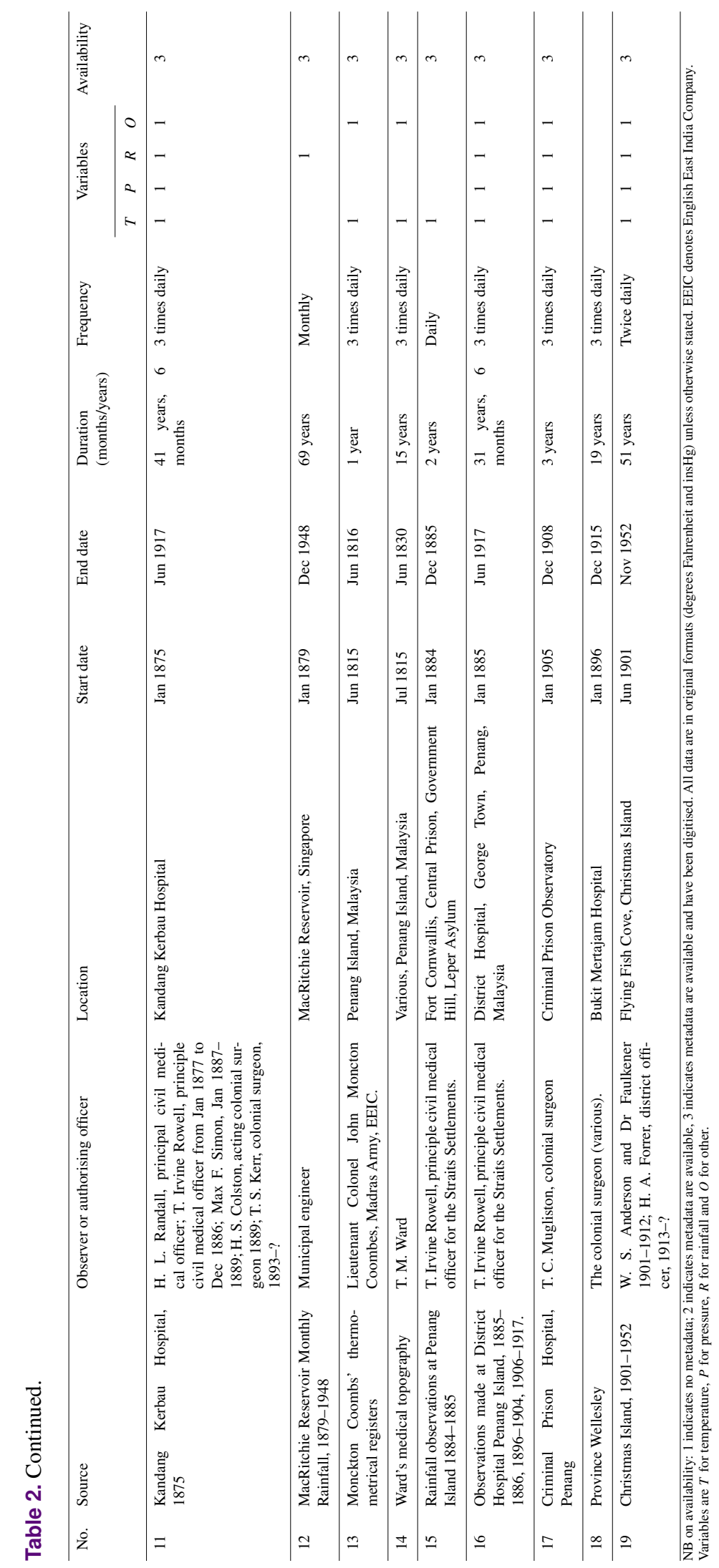




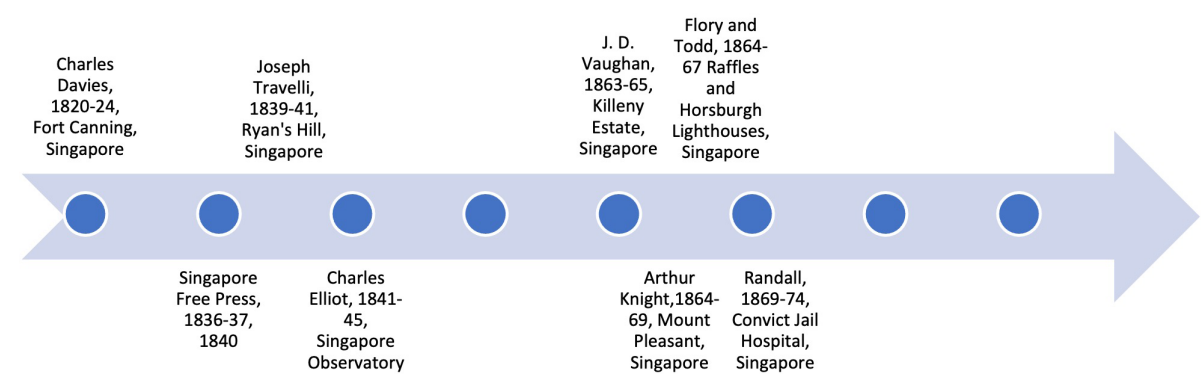

Figure 2. Summary timeline of observations for Singapore, 1820-1948.

\subsection{Historical sources: $1845-1869$}

The periodisation of this section reflects the ending of the magnetic observatory observations in 1845 and the formal introduction of meteorology to the medical department administration in 1869. Between 1845 and the early 1860s, weather data are obscure. It is not clear whether observations were made and have been lost or whether there were no observations made at all. The first surviving attempts at creating a consistent weather record originate from private individuals - plantation owners - who were primarily interested in rainfall as an aid to agricultural productivity.

Jonas Daniel Vaughan was the first and one of the most comprehensive observers of this period. Vaughan's main jobs at this time (such as police magistrate, councillor and lawyer) had little obvious connection with meteorology, but prior to this he had served in the Bengal Marines, before being posted to Singapore as master attendant and marine magistrate (the senior officer in port) in Singapore in 1856 (Gibson-Hill, 1960; Makepeace, 1921). After retiring from this role, he had started a plantation in the River Valley Road area alongside his police duties, on what was then known as the Killeny Estate (Buckley, 1984). He made a series of observations starting in 1863, which were subsequently published in the Straits Settlements Government Gazette over 3 years (e.g. Vaughan, 1865). His neighbour - Arthur Knight - also made inroads into meteorological observation during the same period and into the 1880s at Mount Pleasant in Toa Payoh (Irvine Rowell, 1885). This would have been an incredible long-time series spanning 17 years, but unfortunately only the 1864-1869 data can be found, with the exception of the annual rainfall abstracts (Wheatley, 1881). Into the early 1870s, Alsagoff and Company, who owned lemongrass plantations around the modern-day Geylang area, then called Perseverance Estate, were also responsible for a rainfall series (Straits Settlements Government Gazette, 1875). The family-run business was headed by Syed Omar bin Mohamed Alsagoff, who was a leading member of the local Muslim community and one of the biggest plantation owners in Singapore (Tan, 2009).

The backgrounds of the observers and emphasis placed on rainfall measurement during this period demonstrate the importance of long-term records to local agriculturalists and landowners, but formal, governmental involvement appeared limited. The only authorised observations were those made at Singapore's Horsburgh and Raffles lighthouses from 1864 to 1867 by Thomas Todd (senior keeper) and J. W. Flory (second keeper) respectively (e.g. Todd, 1864). This series is short but very detailed. Observations encompassed pressure, temperature, wind, aspect of the sky, and rainfall by pluviometer, all taken 3 times per daily at sunrise, noon, and sunset. Horsburgh was the first lighthouse to be built through British funding in Singapore, opening in 1850. It was named for Captain James Horsburgh, hydrographer to the EEIC from 1810 to 1836, famed for his surveys and charts of seas in the region. Raffles was the second lighthouse, opening 4 years later and still in operation today. Of any other observations, though the keepers likely continued to make records, no more were published that this author is aware of currently. One plausible reason for this is a change of governance structure in 1867 when the Straits Settlements became a crown colony under direct control of the Colonial Office in London. This was reflected in shifts in the format, scope and content of the government gazettes and, hence, what was published in them.

\subsection{Historical sources: $1869-1917$}

In 1869 , meteorology for the Straits Settlements was finally brought under control of the medical department. The reasons for this were both historic and practical. First, the 19th century had witnessed a surge of interest in what is known as medical meteorology, a field of medical research that based its investigations on connections between health and weather. This concept of disease causation had been inspired by centuries of Hippocratic thought, which placed the environment and climate as significant elements in the construction of human health. Particular peaks, such as very hot and dry weather, followed by exceptionally heavy rains were considered unhealthy, as too were droughts and floods. As the century progressed, a quantitative method of comparing disease incidence with meteorological data became common practice across the colonies of the British Empire (e.g. Walker, 1876, 1925). The collation and correlation of large quantities of statistical data for weather and disease incidence cre- 
ated recognisable medical and scientific frameworks for understanding the relationship between climate and health. The medical department also offered a coherent infrastructure for the systematic collation of observations within a controlled environment directly under the purview of the colonial government.

The first official set of observations under the medical department were made in Singapore at the Convict Jail (Bras Basah) Hospital between 1869 and 1874. This hospital had originally been intended to hold transported prisoners (mainly of Indian origin) from other British colonies. The emphasis was on reformative labour, and the prisoners were engaged in many projects that enabled Singapore to develop as a port town, providing manual and skilled labour for construction, carpentry and so on (Yang, 2003). The weather data are very detailed, using standardised sheets of similar format to those being used across the Straits Settlements and the British colonies at this time. Readings were made three times per day of pressure and temperature (using a wet and dry bulb); there were self-registering thermometers for readings made in the sun, on grass and in shade; a hygrometer for dew point temperature, elastic force of vapour, degree of humidity, and saturation; and of course, rainfall, wind, and remarks on state of weather.

Despite the detailed records, little is known about the small-scale observatory within the prison or who made the observations. The prison itself was designed and established by George Coleman, superintendent of public works and of convicts as an open plan area with numerous workshops and studios, one of which was presumably an observatory space (McNair and Bayliss, 1889). Coleman handed operations to his successor Major John Frederick McNair, also a prominent architect and an engineer. McNair was fluent in Hindustani and - according to some contemporaries - had a good relationship with the predominantly Indian prisoners (The Straits Times, 1884). He may have supervised a subordinate or even a trusted prisoner to make the observations, but they were ultimately signed off on by Colonial Surgeon H. L. Randall. In 1867, the practice of transporting prisoners ended, and some 6 years later, around the time that this observational set ended, most of the transportees had been removed and the original department was disbanded entirely. The story of the hospital thus explains the beginning and the end of this particular dataset.

Kandang Kerbau Hospital took over the meteorological role, becoming the foremost source of governmental public information on the weather for the remainder of the century, despite the presence of conterminous datasets. Kandang Kerbau hospital became the largest medical facility in Singapore, also housing a lock hospital by 1873 (Lee, 1990). The dataset is one of the longest daily time series covering the widest set of perimeters for the Straits Settlements during this period. Their extraordinary survival is the result of the fact that the observations were issued publicly in both government gazettes and the local press. The data include sub-daily pressure and temperature (dry and wet bulb) made at 09:00, 15:00, and 21:00; self-registering thermometers, placed in the sun, on grass, and in the shade; hygrometer readings; precipitation; mean direction of wind; and general remarks on the weather. Again, we do not know who made the observations, but there are references that point to assistant surgeons and apothecaries working at the hospital undertaking the role (Straits Settlements Government Gazette, 1892). By the 1910s the format had changed slightly, with more emphasis on cloud types. The records also note important metadata context, by showing the height at which thermometers and the rain gauge rim were set above the ground.

The Kandang Kerbau observations are not published in the government gazettes beyond 1917, although they were continued to be made. A possible explanation for their public disappearance is that meteorology was moved out of the medical department and into the museums department under Herbert Robinson at around this time. This rather unlikely home could have sounded the end of the continued practice of public weather reports, had it not been for Robinson's own personal interest in the science. Robinson was been critical of prior efforts to create standardised and reliable readings, a problem that - in his opinion - appeared to afflict the rural stations especially. Thus, from 1921, he began to recruit specialist staff and to improve observer's training. His major achievement came in 1924, when he arranged the hire of a dedicated meteorological officer for Malaya. After this, all meteorological returns for the peninsula were collated by specialist clerks in the employ of the museum's department (SEL: SEC 1108/1925). This was the preamble to the establishment of a formal, dedicated Malayan meteorological department in 1929 (Maxwell and Robinson, 1927).

Elsewhere in the Straits Settlements, hospitals were also key to charting the weather. In Penang, the district hospital and the leper hospital, the latter situated on Pulau Jerejak, were the site of continuous datasets throughout the late 19th century. The district hospital records begin in 1885 and - like Kandang Kerbau - follow through to 1917. Their disappearance is likely linked to the changing governance structure for meteorology at that time. The observations follow the same format too, as the medical department issued standardised sheets for the making of sub-daily readings based on the typical British colonial standard.

All the hospital weather observations from across the settlements were signed off on by successive principal chief medical officers (PCMOs) but would have been created by a staff officer, likely the assistant surgeon. The PCMO's attitude toward this overseer's role is also worthy of mention. While all were obliged to maintain the records, those with an active interest in weather science played a critical role in expanding meteorological services across the peninsula. $\mathrm{T}$. Irvine Rowell, who served as PCMO from 1877, is a case in point. His interest in meteorology spanned far beyond the practice of medical meteorology but to understanding how patterns of settlement might have impacted local weather, 


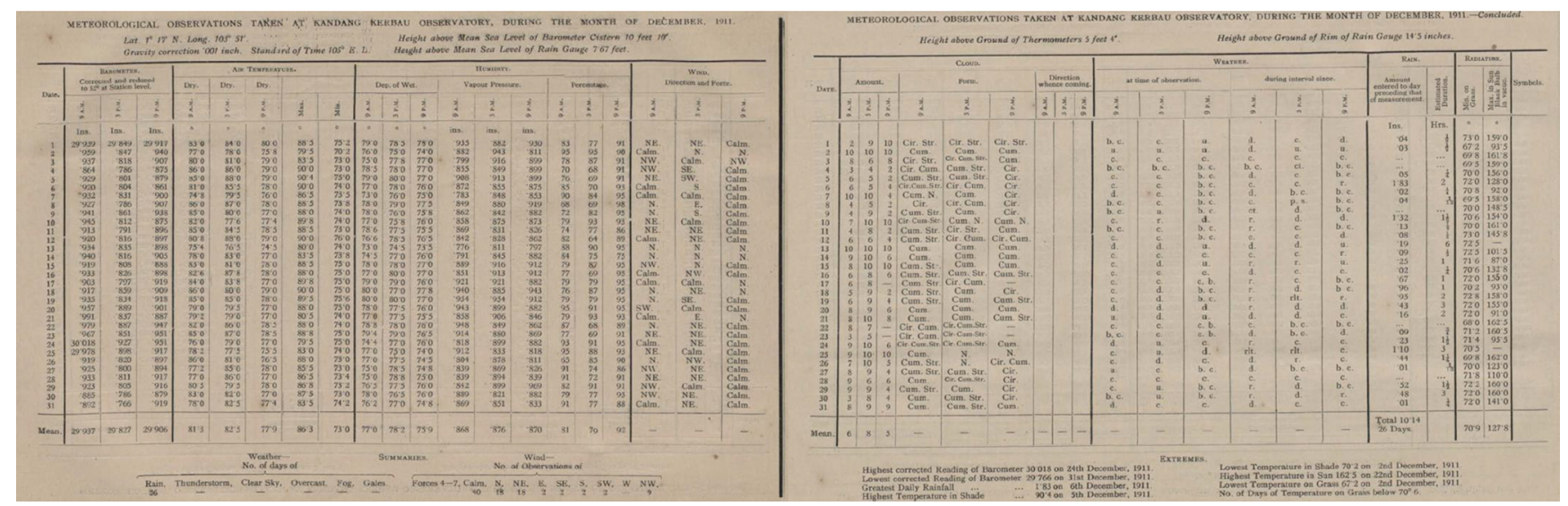

Figure 3. Meteorological observations taken at Kandang Kerbau Observatory, December 1911, published in the Straits Settlements Government Gazette, 11 October 1912, pp. 1609-1610.

especially the purported connection between deforestation and rainfall. Publishing studies using historic observations (Irvine Rowell, 1885), he pushed hard to extend the number of registering stations across the country, especially in rural areas, in order to understand anthropogenic changes in weather.

It is also worth highlighting one other important continuous dataset that has no connection to the medical records. This was made at what is today known as MacRitchie Reservoir, Singapore, from 1879. The reservoir opened after many years of planning and development at the end of 1877 (Williamson, 2020; Broich, 2007). Meteorological observations commenced in 1879 at two rain gauge sites, both of which still exist in almost their original locations today (Gao et al., 2019). Thus, their record serves as the longest continuous rainfall series for Singapore, much of which has been recovered and digitised.

Finally, there is also evidence that observations were made at the central prison and at Government Hill, Penang, during the 1880s and at several other stations in and around Singapore, including at the Pauper Hospital (Tan Tock Seng); the Peninsula and Oriental Steam Navigation depot, the botanical gardens, and the quarantine station at St John's Island during the late 19th century; the new Mount Faber Observatory and Fullerton Building from the 1920s and the Kallang airfield from the 1930s. There is enough evidence, either of reference to observations being made, the existence of abstracts, or of scattered sets of readings themselves, to show that unmined resources exist but, to date, these have not been recovered.

\subsection{Extreme events: droughts and floods}

The detailed weather records that have been recovered, alongside either contextual and narrative evidence from gazettes, newspapers, colonial reports and correspondence, eye-witness accounts and contemporaneous historical writ- ing, reveal a long record of drought and flood across the Malay Peninsula. Indeed, the juxtaposition of data and narrative is more revealing of events that were never purely meteorological but result as much from man's encroachment on natural landscapes and the style and effectiveness of hydraulic engineering and water resource management under the colonial authorities. Some of the worst disasters stemmed not from excessive monsoon rains or, conversely, their failure but from altering natural water courses, urban, industrial or agricultural development on low-lying riverine or coastal areas without proper attention to safeguards or water supply failing to keep up with rapidly expanding populations.

Major flooding events frequently entailed a similar combination of factors: the northeast monsoon (especially at its peak in December); heavy rainfall in combination with a high tide and man-made factors including limited sea defences; a high population density at riverine low-lying land; soil erosion; deforestation and mining activities, among others. While floods affected the Straits Settlements annually, some years proved exceptional, resulting in serious damages, lost livelihoods, and on some occasions population displacement and death. The first severe event recorded during British colonial rule occurred across Penang and Province Wellesley in December 1847. Contemporaries describe flood waters of more than $3 \mathrm{ft}(91.5 \mathrm{~cm})$ when the river burst its banks, inundating plantations and washing away crops with sluice like strength (The Singapore Free Press and Mercantile Advertiser, 1847). In Singapore, it was 4 December 1855 before any severe events were noted, but on that occasion, the roads became impassable under $2 \mathrm{ft}(61 \mathrm{~cm})$ of water, with witnesses describing turbulent weather from the South China Sea and ships grounded in port (The Straits Times, 1855).

Later events are better documented. The 1890s, for instance, were an especially difficult era, with major floods in 1891, 1892, 1893, 1897 and 1899. The 1892 event was especially unusual. Occurring outside of the normal northeast monsoon in May, it quickly became immortalised in commu- 
nity memory as the Great Flood. Pinpointing the event from contemporary newspaper reports and looking at the meteorology from the records of Kandang Kerbau Hospital, we can see an area of low pressure building on 28 May with rainfall of $2.64 \mathrm{~cm}$. The following day, a total $21.5 \mathrm{~cm}$ of rain was recorded within $24 \mathrm{~h}$. Contextual detail from the newspapers also reveals that the majority of this rain fell within $4 \mathrm{~h}$ between 07:00 and 11:00. Contemporary descriptions talk of a phenomenally heavy storm - or a squall from the South China Sea - that broke all records since the hospital observations had begun in 1869. This is corroborated by record of a high south, south-westerly wind made during the 09:00 meteorological reading. The impact of all this on the town can be understood through contemporary official reports and descriptions in the press of damages and clean-up operations, with infrastructural, transport and public health issues all recorded as significant issues (Singapore Free Press and Mercantile Advertiser, 1892).

In the early 20th century, floods were recorded most years, but events in 1909, 1910 and 1925 stand out in Singapore and in 1926 in Malaysia. The series of floods that occurred across the peninsula in late 1925 and into early 1926 were likely linked to strong El Niño-Southern Oscillation (ENSO) conditions that had prevailed across that period, where heavy rains (often in combination with high tides in the Singapore case) created flash flooding, especially following extended dry periods. Reports from the press, photographs and engineering reports help contextualise the meteorological record, aiding in understanding the variable scales and extent of flood impacts across urban and rural parts of Singapore and Malaysia, which had different levels of mitigation, land use and disaster responsiveness. Combining data and narrative reveals the potential value of historical context in fully appreciating the complex and dynamic natural and man-made circumstances that created a disaster (Pfister, 2009; Schenk, 2007).

For droughts, the value of the historical record is similar. Adding to known meteorological observation sets with additional stations or expanding daily or monthly sets with sub-daily data can help improve the quality of historical reanalyses of these events, and complementing this with extra context can augment our understanding of their human impacts. So, for example, while we have a near-global understanding of the physical signature of the 1877-1878 El Niño event (Singh et al., 2018), we can improve and potentially reassess such studies in light of enhanced observation quality and quantity (Huang et al., 2020).

The extended observational set collated during this project for 1877-1878 has been used so far to generate Weather Research and Forecasting (WRF) simulations of modelled and observed event using the NCEP analysis to a greater extent than has been previously attempted, with recently recovered data from seven stations. Below are two examples of simulations created from the observed and WRF modelled precipitation data.
Table 2. Observing stations and coordinates used for the WRF analysis.

\begin{tabular}{ll}
\hline Observing station & Coordinates \\
\hline General Hospital, Sepoy & $1^{\circ} 16^{\prime} 51.1^{\prime \prime} \mathrm{N}, 103^{\circ} 50^{\prime} 10.3^{\prime \prime} \mathrm{E}$ \\
Lines & $1.280846,103.836188$ \\
\hline Kandang Kerbau Hospital & $1^{\circ} 18^{\prime} 24.0^{\prime \prime} \mathrm{N}, 103^{\circ} 50^{\prime} 57.6^{\prime \prime} \mathrm{E}$ \\
& $1.306661,103.849336$ \\
\hline Pauper Hospital (Tan Tock & $1^{\circ} 19^{\prime} 03.5^{\prime \prime} \mathrm{N}, 103^{\circ} 51^{\prime} 27.2^{\prime \prime} \mathrm{E}$ \\
Seng) & $1.317645,103.857547$ \\
\hline MacRitchie Reservoir, & $1^{\circ} 20^{\prime} 36.4^{\prime \prime} \mathrm{N}, 103^{\circ} 50^{\prime} 11.9^{\prime \prime} \mathrm{E}$ \\
Thompson Road & $1.343453,103.836627$ \\
\hline Mount Pleasant, Thompson & $1^{\circ} 19^{\prime} 55.7^{\prime \prime} \mathrm{N}, 103^{\circ} 50^{\prime} 01.1^{\prime \prime} \mathrm{E}$ \\
Road & $1.332141,103.833630$ \\
\hline Convict Jail Hospital, Bras & $1^{\circ} 17^{\prime} 45.0^{\prime \prime} \mathrm{N}, 103^{\circ} 51^{\prime} 01.0^{\prime \prime} \mathrm{E}$ \\
Basah Road & $1.295833,103.850278$ \\
\hline P \& O Co's Depot, New & $1^{\circ} 16^{\prime} 06.1^{\prime \prime} \mathrm{N}, 103^{\circ} 49^{\prime} 22.1^{\prime \prime} \mathrm{E}$ \\
Harbour & $1.268357,103.822805$ \\
\hline
\end{tabular}

The WRF model above was simulated at a spatial resolution of $18 \mathrm{~km}$ using data from the stations noted in Table 2.

To enable comparison against observation locations, the closest grid point from the WRF model was used (Raghavan et al., 2019, 2016; Skamarock, 2008) and, as the simulations spanned historical climate, the WRF model simulations have been forced by NCEP reanalyses using the Twentieth Century Reanalysis V2 and 2c: (https://climatedataguide.ucar.edu/climate-data/ noaa-20th-century-reanalysis-version-2-and-2c, last access: 16 December 2020). ${ }^{1}$ The simulations reveal a relatively close correction between the observed and WRF-generated rainfall.

On the connected subject of how a close lens into such an event can also be used to further contextualise social impacts, comparing the 1877 event with a comparable event in 1911 is revealing of how atmospheric conditions might not always dictate obvious outcomes in the society experiencing them. As a meteorological event, the scale of the El Niño-inspired 1877 drought was especially severe in the Straits Settlements with some of the lowest rainfall ever recorded at that time, though at a smaller scale than the impacts then witnessed in China and India (Davies, 2001). The 1911 event was comparable meteorologically speaking to 1877 but actually resulted in larger-scale and deeper impacts on the people of the Straits Settlements. While thorough analysis of the climatic conditions is essential to understanding what happened, so too are factors including population, environment and infrastructure, especially as these relate to population density in areas

\footnotetext{
${ }^{1}$ 20CRv3 has data for this period, but it currently has a very course resolution and is not useful for Singapore at this stage. A detailed model of this event has not yet been attempted using 20CRv3.
} 

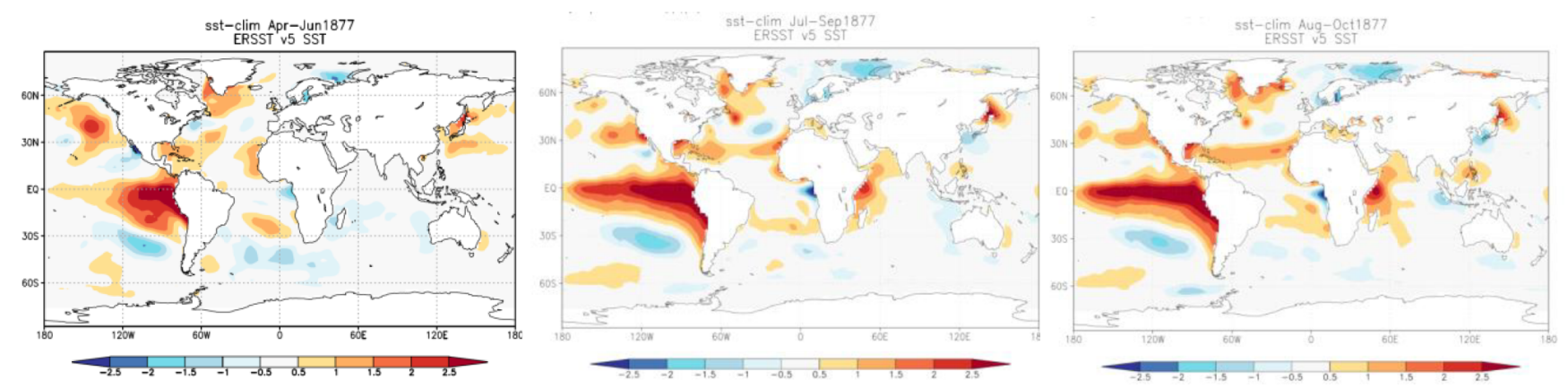

Figure 4. Reconstructions of sea surface temperature (SST) from April to October 1877 generated from the climate data from ERSSTv5 (SST anomalies with respect to the period 1854-2020) available on the WMO Climate Explorer, European Climate Assessment \& Dataset (KMNI) (https://climexp.knmi.nl/start.cgi, last access: 12 December 2020) using in-built correlation software, courtesy of Rob Allan, UK Met Office (UKMO), and lead of the global ACRE initiative.

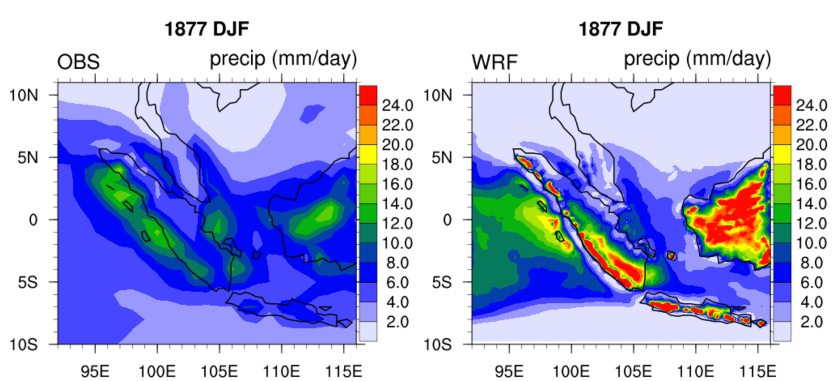

Figure 5. Weather Research and Forecasting (WRF) and OBS simulations of DJF 1877 using observational data from seven stations in Singapore using NCEP reanalyses. Source: Tropical Marine Science Institute (TMSI), National University of Singapore (NUS), 2020 .

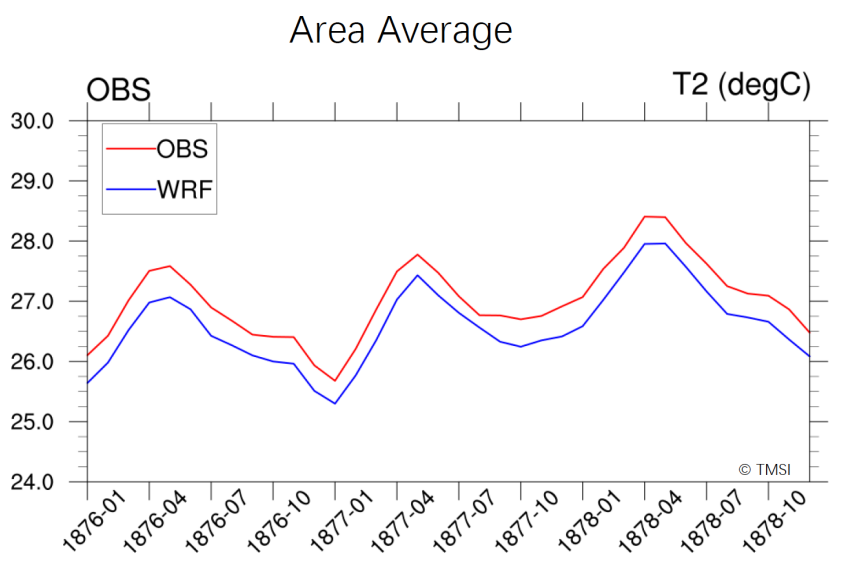

Domain averaged temperature

Figure 6. Correlation of Weather Research and Forecasting (WRF) and OBS simulations of DJF 1877-1878 from seven historic stations in Singapore. Source: Tropical Marine Science Institute (TMSI), National University of Singapore (NUS), 2020. with limited access to water, the scale and quality of extant mitigation measures (such as reservoir capacity), land-use and disaster preparedness. Filling in observational gaps for this region will enable higher-resolution dynamical reanalyses, contextualised with the wider socio-economic, medical, and environmental context within which such events have occurred over time. This has the potential to enable improved frameworks to better inform policy decisions, as well as to improve forecasts of climate variability and impacts.

\section{Conclusions}

The dataset presented here represents only a small portion of the available information for this region and is designed to highlight only the data which have already been through all stages of recovery from archival form to fully digitised and usable sources. There are more data available, but they have not yet been recovered. This paper largely also only focuses on urban Straits Settlements, as weather registering stations did not begin to be established across the whole peninsula until at least the 1880s, and data from these stations are more scattered and, in many cases, have not survived. Much more remains to be done in the pursuit of recovering such records, through initial research to imaging, to ultimately processing into digital formats the remaining records for these two countries, especially in extending the database beyond 1917 and across the peninsula into the Federated Malay States. Eventually, this project also seeks to recover observations from ships' logs, from vessels stationary in port for long periods at Penang, Singapore and Malacca, many of which are located at the UK Hydrographic Office and The National Archives (UK). These data recovery activities fit under the umbrella of the Southeast Asian arm of the global ACRE project, recovery of data for which area will significantly improve the potential for reanalysis of extreme meteorological events in this wider disaster-prone region as well as improve the quality of long-term climate projections. However, data recovery for the peninsula - especially the early focus on towns 
and cities - can be, and is also being, used in other multidisciplinary projects exploring ENSO, urban heat, and the impact of flood and drought on urban settlements including Singapore over time. ${ }^{2}$ While historical sources are not the whole solution to understanding past weather or the complex dynamics and interplay of climate forcings, especially their role in extreme events, they offer one additional layer of information to support reanalyses investigating particular questions or long-term studies of climatic changes.

Data availability. Data are in raw form and available on request to the author.

Competing interests. The author declares that there is no conflict of interest.

Special issue statement. This article is part of the special issue "International methods and comparisons in climate reconstruction and impacts from archives of societies". It is not associated with a conference.

Acknowledgements. The WRF modelling experiments in this study were performed by Srivatsan V. Raghavan and Liu Senfeng at the Tropical Marine Science Institute (TMSI), National University of Singapore (NUS). The author also wishes to thank Rob Allan of the international ACRE project, UK Met Office (UKMO), Hadley Centre, for commenting on earlier drafts of this article and for assistance in providing images, and Ahmad bin Osman, former research assistant at Singapore Management University, for assisting in the collation of data for the 1877 drought under the grant award MOET1-19-C242-SMU-003.

Review statement. This paper was edited by Qing Pei and reviewed by Togo Tsukahara and one anonymous referee.

\section{References}

Allan, R., Endfield, G., Damodaran, V., Adamson, G., Hannaford, M., Carroll, F., Macdonald, N., Groom, N., Jones, J., Williamson, F., Hendy, E., Holper, P., Arroyo-Mora, J. P., Hughes, L., Bickers, R., and Bliuc, A.-M.: Toward integrated historical climate research: the example of the Atmospheric Circulation Reconstructions over the Earth, WIREs Climate Change, 7, 164-174, https://doi.org/10.1002/wcc.379, 2016.

${ }^{2}$ For example, two current projects include "Reconstructing El Niño in Singapore and Malaysia: a multi-disciplinary approach", Singapore Management University, MOET1-19-C242-SMU-003, and "Heat in Urban Asia: Past, Present and Future", National University of Singapore MOE2018-T2-2-120.
Ashcroft, L., Gergis, J., and Karoly, D. J.: A Historical climate dataset for southeastern Australia, 1788-1859, Geosci. Data J., 158-178, https://doi.org/10.1002/gdj3.19, 2014.

Bankoff, G.: Cultures of disaster: Society and Natural Hazards in the Philippines, London, England: Routledge, ISBN 9781138879263, 2003.

Bastin, J.: Raffles and Hastings: Private Exchanges behind the founding of Singapore, Singapore: National Library Board, ISBN 978-981-4561-440, 2014.

Bonney, R.: Francis Light and Penang, Journal of the Malaysian Branch of the Royal Asiatic Society, 38, 135-158, 1965.

Brázdil, R., Dobrovolny, P., Luterbacher, J., Moberg, A., Pfister, C., Wheeler, D., and Zorita, E.: European climate of the past 500 years: new challenges for historical climatology, Clim. Change 101, 7-40, https://doi.org/10.1007/s10584-009-9783-z, 2010.

Brázdil, R., Kiss, A., Luterbacher, J., Nash, D. J., and Rezníčková, L.: Documentary data and the study of past droughts: a global state of the art, Clim. Past, 14, 1915-1960, https://doi.org/10.5194/cp-14-1915-2018, 2018.

Brohan, P., Allan, R., Freeman, E., Wheeler, D., Wilkinson, C., and Williamson, F.: Constraining the temperature history of the past millennium using early instrumental observations, Clim. Past, 8 , 1551-1563, https://doi.org/10.5194/cp-8-1551-2012, 2012.

Broich, J.: Engineering the Empire: British Water Supply Systems and Colonial Societies, 1850-1900, J. Brit. Stud. 46, 346-365, 2007.

Brönnimann, S., Allan, R., Atkinson, R., Buizza, O., Bulygina, P., Dahlgren, D., Dee, R., Dunn, P., Gomes, V., John, S., Jourdain, L., Haimberger, H., Hersbach, J., Kennedy, P., Poli, J., Pulliainen, N., Rayner, R., Saunders, J., Schulz, A., Sterin, A., Stickler, H., Titchner, M., Valente, C., Ventura, C., and Wilkinson, C: Observations for Reanalyses, B. Am. Meteor. Soc., 99, 1851-1866, https://doi.org/10.1175/BAMS-D-17-0229.1, 2018a.

Brönnimann, S., Brugnara, Y., Allan, R. J., Brunet, M., Compo, G. P., Crouthamel, R. I., Jones, P. D., Jourdain, S., Luterbacher, J., Siegmund, P., Valente, M. A., and Wilkinson, C. W.: A roadmap to climate data rescue services, Geosci. Data J., 5, 28 39, https://doi.org/10.1002/gdj3.56, 2018b.

Brönnimann, S., Allan, R., Ashcroft, L., Baer, S., Barriendos, M., Brázdil, R., Brugnara, Y., Brunet, M., Brunetti, M., Chimani, B., Cornes, R., Domínguez-Castro, F., Filipiak, J., Founda, D., Garcia-Herrera, G., Gergis, J., Grab, S., Hannak, L., Huhtamaa, H., Jacobsen, K. S., Jones, P., Jourdain, S., Kiss, A., Lin, KuanHui Elaine, Lorrey, A., Lundstad, E., Luterbacher, J., Mauelshagen, F., Maugeri., M., Maughan, N., Moberg, A., Neukom., R., Nicholson, S., Noone, S., Nordli, O, Ólafsdóttir, K. B., Pearce, P., Pfister, L., Pribyl, K., Przybylak, R., Pudmenzky, C., Rasol, D., Reichenbach, D., Řezníčková, L., Rodrigo, F. S., Rohr, C., Skrynyk, O., Slonosky, V., Thorne, P., Valente, M. A., Vaquero, J. M., Westcott, N. E., Williamson, F., and Wyszyński, P: Unlocking pre-1850 instrumental meteorological records: A global inventory, B. Am. Meteor. Soc., 100, 1-62, 2019.

Brook, T.: The troubled empire: China in the Yuan and Ming dynasties, Cambridge, MA: Belknap Press, ISBN 9780674072534 2010.

Buckley, C. B.: An Anecdotal History of Singapore, 1819-1867, London: Fraser and Neave, 1902.

Cawood, J.: The Magnetic Crusade: Science and politics in early Victorian Britain, Isis, 70, 493-518, 1979. 
Compo, G. P., Whitaker, J. S., Sardeshmukh, P. D., Matsui, N., Allan, R. J., Yin, X., Gleason, B. E., Vose, R. S., Rutledge, G., Bessemoulin, P., Brönnimann, S., Brunet, M., Crouthhamel, R. I., Grant, A. N., Groisman, P. Y., Jones, P. D., Kruk, M. C., Kruger, A. C., Marshall, G. J., Maugeri, M., Mok, H. Y. K., Nordli, Ø., Ross, T. F., Trigo, R. M., Wang, X. L., Woodruff, S. D., and Worley, S. J.: The Twentieth Century Reanalysis Project, Q. J. Roy. Meteor. Soc., 137, 1-28, https://doi.org/10.1002/qj.776, 2011.

Davies, M.: Late Victorian Holocausts: El Niño Famines and the Making of the Third World, London: Verso, ISBN 9781784786625, 2001.

Elliot, C.: The Singapore Observatory (In a note for Dr Little's paper on the Medical Topography of Singapore \&c), Journal of the Indian Archipelago and Eastern Asia, 3, xxxvii-xlvi, 1849.

Gao, E., Timbal, B., and Williamson, F.: Creating Singapore's Longest Monthly Rainfall Record from 1839 to the Present, MSS Res. Lett. 2, 3-11, 2019.

Gibson-Hill, C. A.: The Master Attendants at Singapore, 1819-67, Journal of the Malaysian Branch of the Royal Asiatic Society, 33, 1-64, 1960.

Hsiang, S. M. and Burke, M.: Climate, conflict, and social stability: What does the evidence say?, Clim. Change, 123, 39-55, 2014.

Huang, B., L'Heureux, M., Hu, Z. Z., Yin, X., and Zhang, H. M.: How significant was the $1877 / 78$ El Niño?, J. Clim., 33, 48534869, https://doi.org/10.1175/JCLI-D-19-0650.1, 2020.

Irvine Rowell, T.: Meteorological Report for the year 1885, Journal of the Straits Branch of the Royal Asiatic Society, 16, 385-411, 1885.

Lee, H. F., Zhang, D. D., Pei, Q., Jia, X., and Yue, P. H. R.: Quantitative analysis of the impact of droughts and floods on internal wars in China over the last 500 years, Science China Earth Sciences, 60, 2078-2088, 2017.

Lee, Y. K.: A Short History of the Kandang Kerbau Hospital and the Maternity Services of Singapore, Singapore Med. J., 31, 599613, 1990

Little, R.: An Essay on Coral Reefs as the cause of Blakan Mati Fever etc, Part I: On the medical Topography of Singapore, particularly its Marshes and Malaria', Journal of the Indian Archipelago and Eastern Asia III, VIII, 449-471, 1848.

Logan, J. R.: The Probable Effects on the Climate of Pinang of the Continued Destruction of its Hill Jungles, II, Journal of the Indian Archipelago and Eastern Asia, 2, 534-536, 1848.

Low, J.: A Dissertation on the Soil \& Agriculture of the British Settlement of Penang, Or Prince of Wales Island, in the Straits of Malacca: Including Province Wellesley on the Malayan Peninsula, With Brief References to the Settlements of Singapore \& Malacca, Singapore Free Press Office, 817-818, 1836.

Makepeace, W., Brooke, G., and Braddell, R. St. J.: One-hundred years of Singapore: being some account of the capital of the Straits Settlements from its foundation by Sir Stamford Raffles on the 6th February 1819 to the 6th February 1919, I, London: John Murray, 1921.

Maxwell, G. and Robinson, H. C.: Proposal to establish a Meteorological Department for Malaya: Memorandum on a Pamphlet entitled 'A Meteorological Department for Malaya', written by Victor A. Lowinger, Surveyor General, Federated Malay States and Straits Settlements), 24 October 1927, The National Archives, UK, CO273/541/4, 1927.
McNair, J. F. A. and Bayliss, W. D.: Prisoners their own warders: A Record of the Convict Prison at Singapore in the Straits Settlements, Westminster: Archibald Constable \& Co, available at: https://www.gutenberg.org/files/26974/26974-h/26974-h.htm (last access: 5 February 2021), 1889.

Pfister, C.: Learning from nature-induced disasters: theoretical considerations and case studies from Western Europe, in: Natural disasters, cultural responses: case studies toward a global environmental history, edited by: Mauch, C. and Pfister, Lanham: Lexington Books, 17-40, ISBN 978-0-7391-2415-4, 2009.

Raghavan, V. S., Vu, M. T., and Liong, S. Y.: Regional Climate Simulations over Vietnam using the WRF model, Theor. Appl. Climatol., 126, 161-182, https://doi.org/10.1007/s00704-015-1557$0,2016$.

Raghavan, V. S., Nguyen, N. S., Hur, J., NG, D. H. L., and Liong, S. Y.: Evaluations and Inter-comparisons of Regional Climate Model simulations of Southeast Asian climate: past and future' - Review of current RCM configurations over SE Asia and Singapore', Report submitted to the Centre for Climate Research Singapore (CCRS), Singapore, 2019.

SEL: SEC 1108/1925, National Archives of Malaysia, 1925.

Scaife, A., Good, E., Sun, Y., Yan, Z., Dunstone, N., Ren, H. L., Li, C., Lu, R., Wu, P., Ma, Z, Ke, Z., Furtado, K., Wu, T., Zhou, T., Dunbar, T., Hewitt, C., Golding, N., Zhang, P., Allan, R., Dale, K., Lott, F., Stott, P., Milton, S., Song, L., and Belcher, S.: The Climate Science to Service Partnership - China, J. Meteorol. Res., submitted, 2020.

Schenk, G. J.: Historical disaster research. State of research, concepts, methods and case studies, Hist. Soc. Res., 32, 9-31, 2007.

Singh, D. R., Seager, B. I., Cook, M., Cane, M., Ting, E., and Davies, M.: Climate and the Global Famine of 1876-78, J. Climate, 31, 9445-9467, https://doi.org/10.1175/JCLI-D-180159.1, 2018.

Skamarock, W. C., Klemp, J. B., Dudhia, J., Gill, D. O., Barker, D., Duda, M. G., Huang, X.-y., Wang, W., and Powers, J. G.: A Description of the Advanced Research WRF Version 3 (No. NCAR/TN-475+STR), University Corporation for Atmospheric Research, https://doi.org/10.5065/D68S4MVH, 2008.

Straits Settlements Government Gazette, 13 August, 557, 1875.

Straits Settlements Government Gazette, 21 October, 1892.

Tan, B: Syed Omar bin Mohamed Alsagoff, available at: https://eresources.nlb.gov.sg/infopedia/articles/SIP_1624_ 2009-12-31.html (last access: 10 October 2020), 2009.

The Singapore Free Press and Mercantile Advertiser, 7 December, $1,1847$.

The Singapore Free Press and Mercantile Advertiser, 25 June, 2, 1892.

The Straits Times, 4 December, 4, 1855.

The Straits Times, 4 October, 11, 1884.

Todd, T.: Meteorological Register of the Raffles Lighthouse, for the month of December 1864, Straits Government Gazette, Singapore, $86,1864$.

Vaughan, J. D.: Register at River Valley Road for the Quarter ending December 1864, The Straits Government Gazette 20 January 1865, Singapore, 1865.

Walker, G.: Meteorology in India in Relation to Cholera, Brit. Med. J., 2, 55-56, 1876.

Walker, G.: The Meteorology of India, J. Roy. Soc. Arts, 73, 838$855,1925$. 
Ward, T. M.: Contributions to the Medical Topography of Prince of Wales Island, Or Pulo Pinang', in: Official Papers on the Medical Statistics and Topography of Malacca and Prince of Wales Island and on the Prevailing Diseases of the Tenasserim Coast, edited by: Ward, T. M. and Grant, J. P., Pinang: Government Press, 1830.

Williamson, F.: Responding to Extremes: Urban Water Scarcity in the Nineteenth-Century Straits Settlements, Water History, https://doi.org/10.1007/s12685-020-00260-6, 2020.
Wheatley, J. J. L.: Notes on the Rainfall of Singapore, Journal of the Straits Branch of the Royal Asiatic Society, Singapore, 7, 31-50, 1881.

Yang, A. A.: Indian Convict Workers in Southeast Asia in the late eighteenth and early nineteenth centuries, J. World Hist. 14, 179208, 2003. 